\title{
Transparent $\beta$-Tricalcium Phosphate Ceramics Prepared by Spark Plasma Sintering
}

\author{
Daisuke KAWAGOE, Koji IOKU, Hirotaka FUJIMORI* and Seishi GOTO* \\ Graduate School of Environmental Studies, Tohoku University, Aoba 20, Aramaki, Aoba-ku, Sendai-shi $980-8579$ \\ *Division of Applied Medical Engineering Science, Graduate School of Medicine, Yamaguchi University, \\ 2-16-1, Tokiwadai, Ube-shi 755-8611
}

\author{
放電プラズマ焼結による $\beta$-リン酸三カルシウム透明体の作製 \\ 川越大輔 · 井奥洪二 ·藤森宏高 $*$. 後藤誠史 ${ }^{*}$ \\ 東北大学大学院環境科学研究科環境科学専攻, 980-8579 宮城県仙台市青葉区荒巻字青葉 20 \\ *山口大学大学院医学研究科応用医工学系専攻, 755-8611 山口県宇部市常盤台 2-16-1
}

\begin{abstract}
$\beta$-tricalcium phosphate $\left(\mathrm{Ca}_{3}\left(\mathrm{PO}_{4}\right)_{2}, \beta\right.$-TCP) is known to be biocompatible and osteoconductive. In the present study, $\beta$-TCP ceramics were prepared by the spark plasma sintering (SPS) technique at temperatures ranging from 800 to $1000^{\circ} \mathrm{C}$ at a pressure of $60 \mathrm{MPa}$ for $10 \mathrm{~min}$ at a heating rate of $25^{\circ} \mathrm{C} / \mathrm{min}$. No phases other than $\beta$ TCP were detected in the samples sintered at 800,900 and $1000^{\circ} \mathrm{C}$ by $\mathrm{X}$-ray diffractometry. The relative densities of the $\beta$-TCP ceramics sintered at 800,900 and $1000^{\circ} \mathrm{C}$ were 70,95 and more than $99 \%$, respectively. Transparent $\beta$-TCP ceramics were obtained at $1000^{\circ} \mathrm{C}$ for $10 \mathrm{~min}$. From the results obtained by scanning probe microscopy, the ceramics prepared at 800 and $900{ }^{\circ} \mathrm{C}$ were found to have a few pores. The transparent ceramics had an average grain size of $1.5 \mu \mathrm{m}$ and seemed to be pore-free.
\end{abstract}

[Received January 16, 2004; Accepted May 26, 2004]

Key-words : $\beta$-tricalcium phosphate, Sintering, Spark plasma sintering, Transparent ceramics, Microstructure

\section{Introduction}

$\beta$-tricalcium phosphate $\left(\mathrm{Ca}_{3}\left(\mathrm{PO}_{4}\right)_{2}, \beta\right.$-TCP $)$ is known to be biocompatible and osteoconductive. ${ }^{1)-6)}$ The spark plasma sintering (SPS) method is quite effective for producing dense ceramics of calcium phosphates. ${ }^{7), 8)}$ In the present study, $\beta$ TCP ceramics were prepared by SPS at temperatures ranging from 800 to $1000^{\circ} \mathrm{C}$ at a uniaxial pressure of $60 \mathrm{MPa}$ for 10 min with a heating rate of $25^{\circ} \mathrm{C} / \mathrm{min}$.

A fine powder of $\beta$-TCP (Taihei Chemical Industrial Co., Ltd.) was used as the starting material. This powder of $0.5 \mathrm{~g}$ was placed in a graphite mold ( $8 \mathrm{~mm}$ inner diameter), and then sintered by SPS (Dr Sinter-511S, Sumitomo Coal Mining Co., Ltd., Kanagawa). The temperature of the samples during sintering was measured using a thermocouple of $\mathrm{Rh} / \mathrm{Pt}-\mathrm{Pt}$, inserted into the wall of the graphite mold.

\section{Experimental procedures}

The starting powder and the obtained ceramics were identified using an X-ray powder diffractometer with graphitemonochromatized $\mathrm{Cu} \mathrm{K} \alpha$ radiation, at $40 \mathrm{kV}$ and $20 \mathrm{~mA}$ (Geiger flex 2027, Rigaku). The ceramics were polished with 4000-grid $\mathrm{SiC}$ and further polished with a paste containing fine $\alpha-\mathrm{Al}_{2} \mathrm{O}_{3}$ particles smaller than $0.5 \mu \mathrm{m}$. The Vickers hardness of the samples was measured at a load of $3 \mathrm{~N}$ for $10 \mathrm{~s}$ (AVK-AII, Akashi Seisakusho, Co., Ltd.). The density of the sintered specimens was estimated by the Archimedes immersion technique. After thermal etching at $10^{\circ} \mathrm{C}$ below the sintering temperature for $10 \mathrm{~min}$, the surface of the ceramics was observed by scanning probe microscopy (SPM, Nanopics 2100, Seiko Instruments). SPM was operated with a Si cantilever at a resolution of $0.3 \mathrm{~nm}$. The detected tip amplitude was tuned at $1.0 \mathrm{~V}$.

3. Results and discussion

From the chemical analysis results presented by Taihei Chemical Industrial Co., Ltd., the $\beta$-TCP used contained little

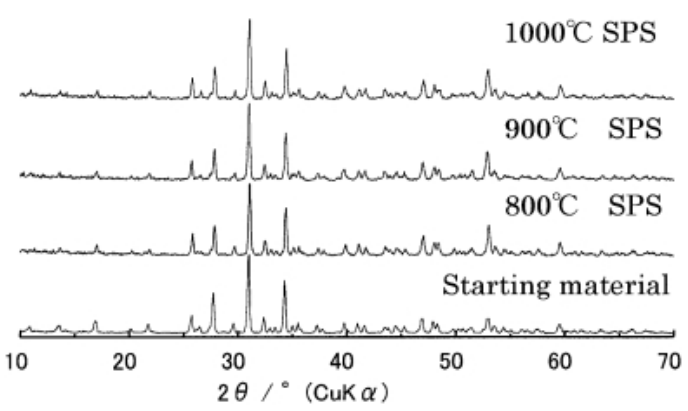

Fig. 1. XRD patterns of starting material and $\beta$-TCP ceramics prepared by SPS at 800,900 and $1000^{\circ} \mathrm{C}$.

impurities: $\mathrm{Cl},<20$ mass ppm; $\mathrm{SO}_{4},<50$ mass ppm; $\mathrm{Fe},<10$ mass ppm; As, <1 mass ppm; Mg, <50 mass ppm; and $\mathrm{Mn}$, $<20$ mass ppm. The XRD patterns of the starting material and the samples prepared by SPS at 800,900 and $1000^{\circ} \mathrm{C}$ for $10 \mathrm{~min}$ (Fig. 1) revealed no second phase other than $\beta$-TCP. Therefore, the starting material of $\beta$-TCP has a stoichiometric $\mathrm{Ca} / \mathrm{P}$ molar ratio of 1.50 . In the SPS process, densification was started at $800^{\circ} \mathrm{C}$, and then proceeded at elevated temperatures. The resultant linear shrinkage was $40 \%$ at $1000^{\circ} \mathrm{C}$, which denotes the end of densification (Fig. 2). The $\beta$-TCP ceramics prepared by SPS at 800,900 and $1000^{\circ} \mathrm{C}$ had relative densities of 70,95 and more than $99 \%$ and Vickers hardness of 2.5, 4.8 and 5.0 GPa, respectively (Fig. 3). The densification temperature of the SPS process became $200^{\circ} \mathrm{C}$ lower than that of the normal sintering process. ${ }^{9)-11)}$ In particular, the sintering was completed within a short time. Transparent $\beta$-TCP ceramics were obtained by SPS at $1000^{\circ} \mathrm{C}$ for $10 \mathrm{~min}$ (Fig. 4). Kondoh et al. ${ }^{12)}$ reported that the transparent $\beta$-TCP ceramics were obtained by HIP'ing above $1000^{\circ} \mathrm{C}$ at a pressure of 100 $\mathrm{MPa}$ for $30 \mathrm{~min}$. The present result demonstrated that SPS is 


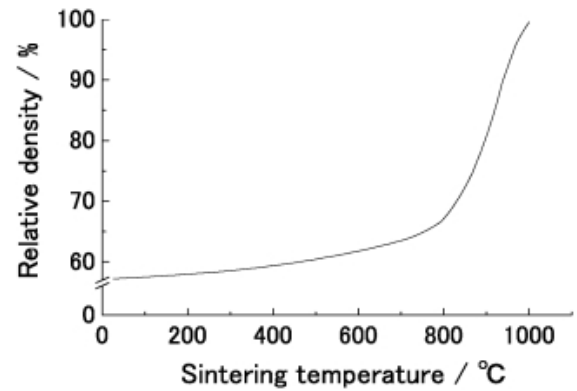

Fig. 2. Relative density of $\beta$-TCP ceramics prepared by SPS at indicated temperatures.

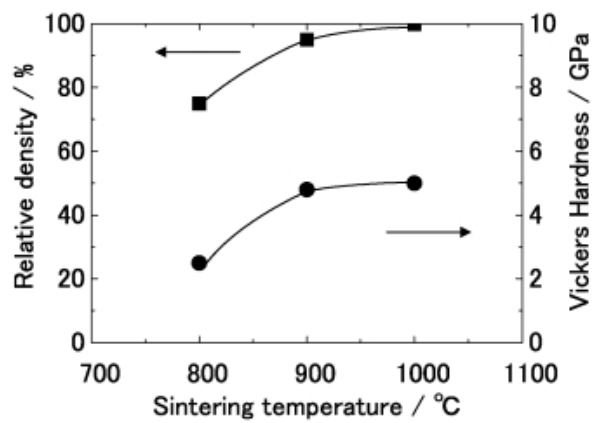

Fig. 3. Relative density and Vickers hardness of $\beta$-TCP ceramics prepared by SPS at 800,900 and $1000^{\circ} \mathrm{C}$.

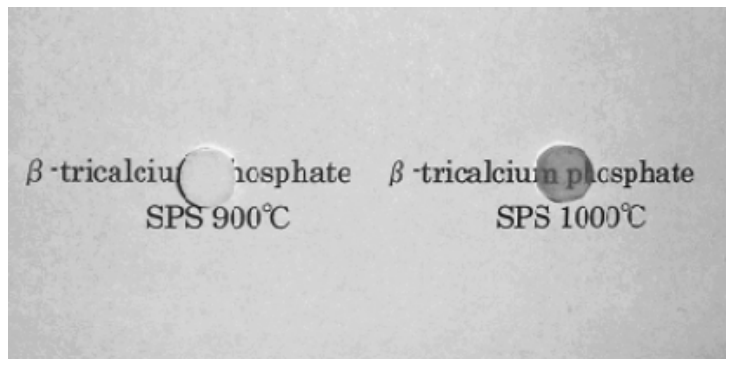

Fig. 4. $\beta$-TCP ceramics prepared by SPS at 900 and $1000^{\circ} \mathrm{C}$.

an available method for fabricating highly densified $\beta$-TCP ceramics. From SPM observations, the ceramics prepared at $800^{\circ} \mathrm{C}$ had a few pores of $0.1 \mu \mathrm{m}$ diameter. The SPM image of the transparent ceramics prepared at $1000^{\circ} \mathrm{C}$ after the etching is shown in Fig. 5. The average grain sizes of the ceramics sintered at 800,900 and $1000^{\circ} \mathrm{C}$ were $0.8,1.0$ and $1.5 \mu \mathrm{m}$, respectively, and there was almost no pore in the transparent ceramics. The transparent $\beta$-TCP ceramics prepared in this study must be used in directly observing cultured cells.

Acknowledgement The authors thank the Collaborative

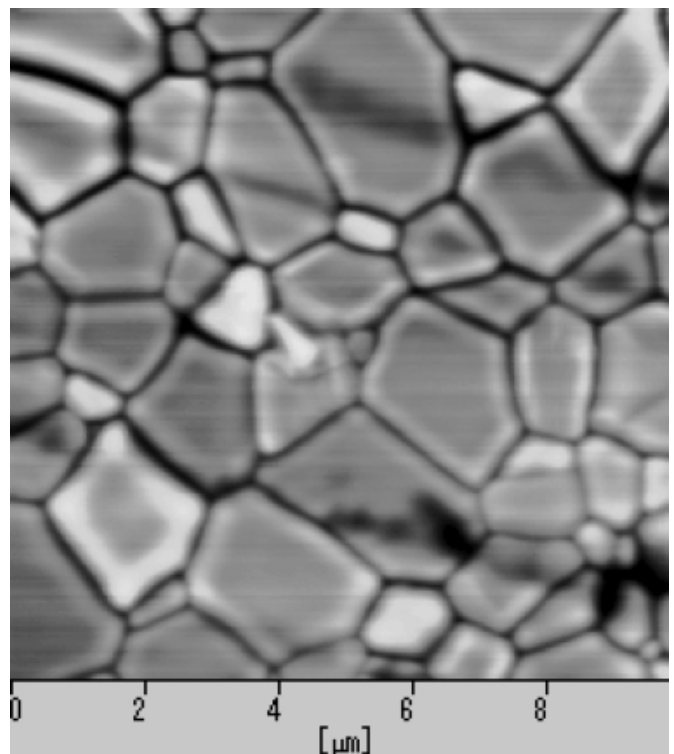

Fig. 5. SPM image of transparent $\beta$-TCP ceramics prepared by SPS at $1000^{\circ} \mathrm{C}$.

Research Center, Yamaguchi University, for the use of the spark plasma sintering apparatus and Yamato Scientific Co., Ltd., for the use of the scanning probe microscope.

\section{References}

1) Akao, M., Ceramics Japan, Vol. 20, pp. 1096-1103 (1985) [in Japanese].

2) Aoki, H., Inami, Y. and Ito, A., "Bioceramics-Development and Clinical Applications," Ed. by Aoki, H. and Niwa, S., Quintessence Publishing (1987) pp. 86-90 [in Japanese].

3) Ioku, K., Inorg. Mater. Japan, Vol. 3, pp. 412-418 (1996) [in Japanese].

4) Yokozeki, H., Hayashi, T., Nakagawa, T., Kurosawa, H., Shibuya, K. and Ioku, K., J. Mater. Sci. Mater. Med., Vol. 9, pp. 381-384 (1998).

5) Kondo, K., Phosphorus Letter, No. 36, pp. 23-26 (1999) [in Japanese].

6) Hakamatsuka, Y. and Irie, H., Phosphorus Letter, No. 37, pp. 9-13 (2000) [in Japanese].

7) Nakahira, A., Tamai, M., Aritani, H., Nakamura, S. and Yamashita, K., J. Biomed. Mater. Res., Vol. 62, pp. 550-557 (2002).

8) Ioku, K., Kawagoe, D., Toya, H., Fujimori, H., Goto, S., Ishida, K., Mikuni, A. and Mae, H., Trans. Mater. Res. Soc. Japan, Vol. 27, pp. 447-449 (2002).

9) Jarcho, M., Salsbury, R. L., Thomas, M. B. and Doremus, R. H., J. Mater. Sci., Vol. 14, pp. 142-150 (1979).

10) Akao, M., Aoki, H., Kato, K. and Sato, A., J. Mater. Sci., Vol. 17 , pp. 343-346 (1982).

11) Toriyama, M. and Kawamura, S., J. Ceram. Soc. Japan (Yogyo-Kyokai-Shi), Vol. 95, pp. 741-745 (1987) [in Japanese].

12) Kondoh, I., Tamari, N. and Kinoshita, M., J. Ceram. Soc. Japan (Seramikkusu Ronbunshi), Vol. 97, pp. 965-967 (1989) [in Japanese]. 